https://doi.org/10.25143/socr.13.2019.1.042-049

\title{
Phenomenon of Corruption, Its Origin in the Grand Duchy of Finland and the Level in Modern Finland
}

\author{
Dr. iur, MFA, Vladimir Jilkine \\ Law center, Helsinki, Finland \\ info@lawcenter.fi
}

\begin{abstract}
Power and corruption have been inseparable since ancient times. The phenomenon of corruption is of particular interest not only for scientists working in the field of social and humanitarian knowledge, but also for politicians, lawyers, philosophers and public figures. Almost all modern researchers consider corruption as a social phenomenon. The problems of corruption are reflected in the works of political scientists, economists, legal scholars, lawyers, philosophers, sociologists, offering a variety of approaches to the study of a multidimensional and debatable phenomenon. The UN views corruption as a complex social, cultural and economic phenomenon affecting all countries, but does not provide a more detailed explanation of the term. The concept of a "corruption offense" does not have a separate definition in Finnish legislation. Scientists and practitioners still have not come to a common opinion on the key issue: how to objectively determine the effective work of the anti-corruption institution and its impact on the corruption situation in the country. According to the author, studying the history, causes and extent of corruption in Finland will allow understanding of its evolution, causes and influence on the state to determine the regulatory framework in the field of anti-corruption legislation in Finland.

Keywords: historical roots of corruption, phenomenon of corruption, Grand Duchy of Finland, corruption levels, international cooperation.

Plato argued that in the history of mankind there has not yet been a state in which corruption did not shake the peak of political power with its vice. The writings of Aristotle, N. Machiavelli, T. Hobbes, S. Montesquieu on the state and public administration addressed the reasons for the existence, nature and consequences of corruption, its impact on social development. Also today these problems remain important and topical
\end{abstract}


due to the fact that almost all states, as mentioned above, are faced to one degree or another with manifestations of corruption.

The phenomenon of corruption is of particular interest not only for scientists working in the field of social and humanitarian knowledge, but also for politicians, lawyers, philosophers and public figures.

Almost all modern researchers consider corruption as a social phenomenon. The problems of corruption are reflected in the works of political scientists, economists, lawyers, philosophers, sociologists, offering a variety of approaches to the study of a multidimensional and debatable phenomenon.

Studying the history of corruption as a phenomenon after the Grand Duchy of Finland joined the Russian Empire will help understand the tendency and level of corruption in Finland in the $21^{\text {st }}$ century, as well as assessing the effectiveness of anti-corruption measures to create its own specialised institutions to prevent and combat corruption and reduce its level. The accumulated historical experience of Finland, international experience and coordination of international cooperation will help to provide additional guidance in the implementation of the criteria for the effectiveness of anti-corruption institutions in fighting corruption.

Studies by Finnish historians indicate the emergence of corruption long before the formation of the Grand Duchy of Finland.

The local Swedish merchants, who in 1710 received Peter I guarantees of privileges for the oath to the Russian throne, began to actively hold official positions in magistrates and courts, and from 1744 after the transformation of the Vyborg guberniya at the behest of Empress Elizabeth and in the provincial government.

Thus, Ph.D., associate professor in the field of municipal politics Silvo Kaasalainen reports that scholars and historians know that as early as the $18^{\text {th }}$ century in SwedenFinland, government posts were brazenly bought and sold. ${ }^{1}$

For example, Markku Kuisma, a Finnish professor of history, Ph.D., writes that as early as the 1770s, businessmen were playing a dual role in appointing crown fochts. ${ }^{2}$ This, however, did not lead to the emergence of special problems with the removal from office, even though they had "important administrative tasks to regulate sawmill from determining the amount of taxes to controlling production". ${ }^{3}$

${ }^{1}$ Kaasalainen, S. Virkanimitysruletti: miksi sopivin voittaa parhaan? Barrikadi-sarja No 22 (Eng. Appointment Roulette: Why is it best to win the best? Barricade Series No 22). Helsinki: WSOY. Werner Söderström Oy, 2011.

2 A state official in the Grand Duchy of Finland as the highest police officer, who was also a prosecutor, tax collector and bailiff. He also represented the executive branch in which the governorship generals acted as well as entrepreneurs (post was abolished only in 1945).

3 Kuisma, M. Kauppasahojen perustaminen Suomessa 1700-luvulla: Tutkimus päätöksentekoprosessista (Eng. Establishment of Trade Saws in Finland in the $18^{\text {th }}$ century: A study of the decisionmaking process). Väitöskirja. Helsinki: Societas Scientiarum Fennica. 1983. p.19. 
In March 1808, the Emperor and Autocrat All-Russian Alexander I announced to foreign states that he decided to unite Finland with his empire. On 5 (17) June 1808, Alexander I issued a manifesto "On the Accession of Finland", which stated that the emperor decided that Finland, under the rule of the Russian emperor, should live under the protection of its old constitutions and privileges. The members of the Sejm took the oath that "they recognise as their sovereign Alexander I the Emperor and Autocrat of the All-Russian Grand Duke of Finland, and they will preserve the fundamental laws and constitutions of the region as they currently exist". ${ }^{4}$

According to Markku Kuisma, the merchant class, which was engaged in sawmill production in the late 1700 s, was able to take power over a "plutocratic" or rich city administration. Large merchants and ship-owners also had better chances to influence government decisions and manage their own interests. ${ }^{5}$

Kuisma describes the history of the relationship between business, politics and government elites in the 1800s, when the "industrial aristocracy" and the new business class developed. The industrial aristocracy and the class of entrepreneurs were connected by family and family contacts with the old elite of officials, the class of teachers and owners of family estates and at the same time had political power. The advanced son of a lawyer or the son-in-law of the professor, the uncle of the capital senator who owns the sawmill, the governor's godson and cousin of the judge, the brother-in-law's brother-in-law who took the post of industrialist, and the Secretary of State of the Interparliamentary Assembly of St. Petersburg formed a network of interconnected, loyal and interdependent organizations of the Inter-Parliamentary Assembly of St. Petersburg. or wanted to influence the decisions of the power system. ${ }^{6}$

Kuisma concludes that a brief historical overview shows that the business community, especially the "timber industry bourgeois", tried to influence government decision making from the end of the $18^{\text {th }}$ century, giving gifts and corrupting officials. This practice was not new or unprecedented. ${ }^{7}$

After the defeat of Russia in the war with Japan, the internal political opposition to the imperial regime intensified. Unrest spread to Finland, where at the end of October 1905 a general strike began. The unrest led to the royal manifesto on the establishment of a parliament in Finland on the basis of the universal right to vote, with the authority to ensure the legitimacy of the measures taken by the government of the country.

${ }^{4}$ Rafael, E. Suomen valtio-oikeus. Tietosanakirja (Eng. Finnish State Law. Encyclopedia). Helsinki: Osakeyhtiön Kirjastopaino, 1924. p.42-43.

${ }^{5}$ Kuisma, M. Kauppasahojen perustaminen Suomessa 1700-luvulla: Tutkimus päätöksente- koprosessista (Eng. Establishment of Trade Saws in Finland in the $18^{\text {th }}$ century: A study of the decisionmaking process). Väitöskirja. Helsinki: Societas Scientiarum Fennica, 1983. p.150.

${ }^{6}$ Kuisma, M. Kauppasahojen perustaminen Suomessa 1700-luvulla: Tutkimus päätöksente- koprosessista (Eng. Establishment of Trade Saws in Finland in the $18^{\text {th }}$ century: A study of the decisionmaking process). Väitöskirja. Helsinki: Societas Scientiarum Fennica, 1983. p. 178.

7 Ibid., p. 150. 
The parliamentary reform of 1906 accelerated the creation of political parties and over the past decades political parties have become a central part of all political activity. After the adoption of the law on parties in 1969, the parties were also a legally integral part of state institutions that still influence government decision-making.

Before the parliamentary elections of 1922, the trade and industry election commission announced that it would finance campaigns of bourgeois parties, subject to nomination of candidates approved by business as general candidates.

During the parliamentary elections of 1939, the industry began to plan collection of electoral funds to influence and direct agitational work on the peasantry and the "middle class". ${ }^{8}$

The amount of bribes received in $1970-1980$ by officials in Finland according to the charges ranged from 1,000 to 28,000 Finnish marks (168-4,706 euros). At the same time, according to the Statistical Center, the average monthly salary (in terms of Finnish marks) in Finland in 1960 was 77 euros, in 1980 it was 625 euros. ${ }^{9}$

In addition, in the courts of Finland quite often criminal charges of corruption offenses were considered simultaneously with the charges under economic articles; therefore, there is no exact data on the number of convictions in receiving and paying bribes.

Hidden crime in Finland was studied in 1973 by a professor at the University of Tampere, Pertti Hemanus. From his point of view, "Hidden crime is a problem in the fight against bribery and corruption in general. The information obtained from statistics does not give a complete picture of the reality of corruption". ${ }^{10}$

Ahti Laitinen, a doctor of political science and a professor of criminology, wrote about the role of the president back in 1986:
"Although in practice the president submits a foreign policy report to both the Foreign Affairs Committee of the Parliament and the government, in practice the role of Parliament in managing foreign policy is secondary. The weakening of the position of Parliament in the system of relations of state power is partly due to the circumvention of the policy around the president, which was especially noticeable in Finland in the 1960s and 1970s". 11

In the early 1980s, the change of power of higher state institutions was initially caused only by a change of president, and then rather quickly progressed to significant changes to the constitution and the separation of government power. Already

\footnotetext{
${ }^{8}$ Kuisma, M. Kauppasahojen perustaminen Suomessa 1700-luvulla: Tutkimus päätöksente-koprosessista (Eng. Establishment of Trade Saws in Finland in the $18^{\text {th }}$ century: A study of the decisionmaking process). Väitöskirja. Helsinki: Societas Scientiarum Fennica. 1983. p. 85. URL: https:// www.stat.fi/artikkelit/2012/art_2012-03-12_004.html.

9 URL: https://www.stat.fi/artikkelit/2012/art_2012-03-12_004.html.

${ }^{10}$ Hemanus Pertti. Joukkotiedotus piilovaikuttajana (Eng. Mass media as a hidden influence). Delfiinikirjat. Helsinki: Otava, 1973. p. 109.

${ }^{11}$ Laitinen, A. Yhteiskunnallinen vallankäyttö ja korruption mahdollisuudet (Eng. Social use of power and opportunities for corruption). Turku. 1986. p. 54.
} 
in the 1970s and at the turn of the 1980s, a period of change and transformation of the elite began.

The topic of bribing civil servants became widely discussed in the second half of the 1970s in connection with the so-called Salora case. According to the court's decision, Salora's CEO Jouko Nordell bribed politicians and senior officials and paid for their travel abroad. 6 million Finnish marks passed by the financial statements. As a result, the company's general director received 3.5 years in prison for bribing five ministers, two heads of office, the mayor and 30 employees of the tax department.

In the 1980s, wide public attention was directed to discussing a number of cases of bribing officials, trust and impartiality of government.

In 2009, Finnish State Attorney Jukka Rappe stated that there is no structural corruption in Finland, but there is a well-established scheme of "cronyism" (hyvä veli verkosto) according to the "You to me - I to you". Corruption in power was the subject of many Finnish political scientists and lawyers in the years 1970-1980.

During the presidential term of Urho Kekkonen, many government ministers Harri Hermanni Holkeri (30.04.1987-26.4.1991) received high-ranking positions. For example, Kalevi Sorsa on the Executive Board of the Bank of Finland, Erkki Liikanen was appointed ambassador to the European Union, Ilkka Suominen as director of Alko, Pekka Vennamo as director general of the post office and television broadcasting, Helena Pesola as director of the pension department, and Kai Bärlund as director general of the environment center, and 1995-2007 Head of the UNECE Environment Commission.

Previously appointed Minister of the Interior (1982-1983), Minister of the Environment (1983-1987) Matti Ahde, after the expiration of his term as deputy speaker of the Finnish Parliament in 1990, was immediately appointed managing director and elected a member of the board, and then chairman of the board in 1990-1999 State Association of slot machines of Finland RAY.

Also note that Holkeri government reforms have significantly increased the number of civil servants in ministries. At the beginning of the Harri Holkeri government (1988-1991), the government apparatus numbered 214,000 civil servants, and in 1990 it was 147,000 people, and by 1995 it was 124,000 . For comparison, in 2010 the number of civil servants in Finland exceeded 80,000.

The condition of the long-term stability of the activities of public servants in Finland is partly reflected in the fact that the State Civil Service Act of 1924 remained in force for more than 60 years - until 1986.

One of the effective social technologies to combat corruption is the formation of public consciousness of zero tolerance for corruption crimes in Finland. This is possible only if the formation of an anti-corruption outlook and therefore the main role belongs to the media.

Analysis of scientific publications and generalisations of court practice lead to the conclusion that corruption in Finland has a very high latency. Reports of the Ministry of Justice, the highest police school indicate the real situation of corruption in Finland, 
including the hidden corruption in many areas of municipalities. Bribery, however, is only one form of corruption. Corruption is also noted in cases of "acquaintance" relations, in cases of nepotism or nepotism, as well as violations of good management and administration practices.

Special mention should be made of the special role of journalists and the frequency of coverage of Finnish media on television channels of information on corruption facts among members of the parliament, senior police and prosecutors, and representatives of big business with further coverage of court hearings and court decisions.

For example, in their investigation journalists Tuomo Pietiläinen and Niko Vartiainen presented a pre-election analysis of the Finnish representatives of the municipal government.

"Now there are 395 politicians in the municipal councils of Finland who over the past five years have been convicted of committing a total of 705 offenses during the period 2012-2017. Of these, 99 politicians were sentenced to prison or to a suspended prison sentence. During this period, Finnish politicians received charges of beating and causing harm to life and health in 140 crimes. The degree of intoxication of $2.5 \mathrm{ppm}$ of alcohol and more was recorded in seven politicians, and the maximum level of alcohol was 3.11 ppm was recorded in Finnish politics in 2015". ${ }^{12}$

Before the parliamentary elections in 2019, journalists presented new data: in the period 2005-2019. 318 deputies who are candidates for the parliament in the elections of April 14, 2019, were charged with criminal offenses, which accounted for $12.9 \%$ of the total number of 2,468 candidates for deputies. Among women candidates, criminal charges accounted for $14 \%$.

For example, only in one party of the Seven Stars Movement out of 175 declared candidates, 103 had criminal charges. The sentence of imprisonment for 3 years and 4 months for aiding in a serious drug offense was received on February 11, 2018 by a candidate for the Parliament of Kim Holviala, awaiting a review of the case in the appellate court at large. For attempted murder and the threat of murder or the infliction of grievous bodily harm, the candidate for the Parliament Sami Salonen was sentenced to 3 years and 6 months in prison. The maximum penalty among female candidates for Parliament is the county court determined Minna Engström for a period of 1 year and 4 months for a serious economic crime and further banned business activities until the end of $2021 .^{13}$

Analysing judicial practice in Finland, it can be concluded that the courts of all instances apply much less severe penalties, for example, imposing minor fines.

12 Pietiläinen, T., Vartiainen, N. Kuntapäättäjien rikoksia piilossa äänestäjiltä (Eng. Crimes of municipal decision-makers are hidden from the voters). HS. 24.9.2017.

13 Pietiläinen,T., Räisänen, K., Laatinen, J. Sadat edusuntaan pyrkivät olleet syytteessä rikoksista (Eng. Hundreds of leaders have been charged with crimes). HS. 7.4.2019. 
To prevent corruption, it is necessary to develop policies, analytical research, monitoring and coordination of actions to combat corruption, as well as monitoring their implementation and evaluating their effectiveness.

It is necessary to prevent conflicts of interest, check declarations of property of officials and ensure public access to this information. Mechanisms for the implementation of these functions can be financial control, measures to prevent legalisation of proceeds of crime, measures to achieve transparency in public procurement.

The preventive function is to increase the transparency of the public service, ensure open access to information by the public and ensure control over financing of activities and elections of political parties.

Education and educational function includes development and conduct of educational programmes for the public and public servants, and work with the media, public organisations and the public.

In conclusion, it is necessary to emphasise that there is no single recipe for resisting corruption. The fight against corruption requires close coordination of international cooperation and law enforcement agencies, analysis of statistical data on corruption cases, provision of legal assistance, execution of extradition court decisions and international readmission obligations.

\section{Korupcijas fenomens, tā aizsākumi Somijas Lielhercogistē un loma mūsdienu Somijā}

\section{Kopsavilkums}

Ietekme un korupcija ir bijuši saistīi kopš seniem laikiem. Korupcijas fenomens ir īpaši saistošs ne vien sociālo un humanitāro zinātṇu ekspertiem, bet arī politiḳiem, juristiem, filozofiem un sabiedrību ietekmējošām personībām. Gandrīz visi mūsdienu pētnieki uzskata korupciju par sociāla tipa fenomenu. Korupcijas riskus un to ietekmi apraksta politikas zinātnes pārstāvji, ekonomisti, jurisprudences akadēmiskais personāls, filozofi, sociologi, piedāvājot dažādas pieejas šì multidimensionālā un diskusiju vērtā fenomena aplūkošanā. ANO definē korupciju kā kompleksu sociālo, kultūras un ekonomikas fenomenu, kas ietekmē visas valstis, bet sīkāku termina skaidrojumu tam nesniedz. "Korupcijas pārkāpuma" konceptam arī somu likumdošanā nav savas definīcijas. Pètnieki un praktiḳi līdz šim nav vienojušies par kopēju redzējumu korupcijas sakarā: kā objektīvi izvērtēt pretkorupcijas institūciju darba efektivitāti un to ietekmi uz korupcijas risku mazināšanu valstì. Pēc šì raksta autora domām, korupcijas vēstures liecību, cēloṇu un apjoma pētījumi l̦aus izprast šĩ fenomena attīstìbas tendences valstī, tās cēloṇus un ietekmi uz valsts pārvades struktūru, un sekmēs tādas likumdošanas izstrādi, kas regulē korupcijas risku mazināšanu Somijā. 
Vladimir Jilkine. Phenomenon of Corruption, Its Origin in the Grand Duchy of Finland and the Level in Modern Finland

Atslēgvārdi: korupcijas vēsturiskā izcelsme, korupcijas fenomens, Somijas Lielhercogiste, korupcijas līmeṇi, starptautiskā sadarbība.

\section{References}

1. Hemanus, P. (1973). Joukkotiedotus piilovaikuttajana (Eng. Mass media as a hidden influence). Delfiinikirjat. Helsinki: Otava.

2. Kaasalainen, S. (2011). Virkanimitysruletti: miksi sopivin voittaa parhaan? Barrikadi-sarja No 22 (Eng. Appointment Roulette: Why is it best to win the best? Barricade Series No 22). WSOY. Werner Söderström Oy. Helsinki.

3. Kuisma, M. (1983). Kauppasahojen perustaminen Suomessa 1700-luvulla: Tutkimus päätöksentekoprosessista (Eng. Establishment of Trade Saws in Finland in the $18^{\text {th }}$ century: A study of the decision-making process). Väitöskirja. Helsinki: Societas Scientiarum Fennica.

4. Laitinen, A. (1986). Yhteiskunnallinen vallankäyttö ja korruption mahdollisuudet (Eng. Social use of power and opportunities for corruption). Turku.

5. Pietiläinen, T., Vartiainen, N. Kuntapäättäjien rikoksia piilossa äänestäjiltä (Eng. Crimes of municipal decision-makers are hidden from the voters). HS. 24.9.2017.

6. Rafael, E. (1924). Suomen valtio-oikeus. Tietosanakirja (Eng. Finnish State Law. Encyclopedia). Helsinki: Osakeyhtiön Kirjastopaino.

7. Pietiläinen, T., Räisänen, K., Laatinen, J. Sadat edusuntaan pyrkivät olleet syytteessä rikoksista (Eng. Hundreds of leaders have been charged with crimes). Helsingin Sanomat. 7.4.2019. 